\title{
EXPLORING INDONESIA-PARAGUAY TRADE POTENTIALS: A REVEALED COMPARATIVE ADVANTAGE APPROACH
}

\author{
Sulthon Sjahril Sabaruddin1) \\ Sihar Tambun2) \\ 1)Center for Policy Analysis and Development on American and European Region, \\ Ministry of Foreign Affairs of the Republic of Indonesia, Jakarta, Indonesia \\ 2)Faculty of Economics, Universitas 17 Agustus 1945 Jakarta, Indonesia \\ e-Mail: sulthon.sjahril@kemlu.go.id
}

\begin{abstract}
ABSTRAK
Artikel ini akan menganalisis potensi perdagangan bilateral antara Indonesia-Paraguay berdasarkan daya saing ekspor masing-masing. Tulisan ini dalam analisisnya menggunakan Comparative Advantage Index untuk tahun 2012 yang diperoleh dari World Integrated Trade Solution (WITS). Makalah ini mengungkapkan bahwa ada peluang besar bagi kedua negara untuk lebih memperkuat hubungan perdagangan bilateral. Berdasarkan analisis RCA Index, diungkapkan bahwa secara umum kedua negaratelah mengekspor komoditas mereka berdasarkan keunggulan komparatif masing-masing, namun bagaimanapun ekspor kedua Negara saat ini tidak mencerminkan potensi mereka, Paraguay (tidak untuk Indonesia) yang sepuluh komoditas unggulannya dengan keunggulan komparatif yang kuat tidak dapat menembus pasar kedua belah pihak. Studi ini menyarankan kedua Negara harus menghapus hambatan perdagangan mulai dengan menyediakan akses untuk 10 komoditas ekspor dengan keunggulan komparatif kuat untuk masuk di kedua negara. Langkah ini bias menjadi batuloncatan menuju penguatan hubungan perdagangan bilateral.
\end{abstract}

Kata kunci: daya saing ekspor, hubungan perdagangan bilateral, keunggulan komparatif.

\begin{abstract}
This paper attempts to analyze the Indonesia-Paraguay bilateral trade potentials based on their respective export competitiveness. The analysis uses the Revealed Comparative Advantage Index for year 2012 obtained from World Integrated Trade Solution (WITS). The paper reveals that there are huge opportunities for both countries to further strengthen bilateral trade relations. Based on the RCA Index analysis, the paper revealed that in general both countries have exported their commodities based on their respective comparative advantages, but however both countries current exports still do not reflect their potentials as most for Paraguay (none for Indonesia) of the top ten commodities with the strongest comparative advantage were unable to penetrate both sides market. This study suggests both countries should remove trade barriers starting by providing access for the top 10 export commodities with the strongest comparative advantage to penetrate in both countries. This step could be a stepping stone towards strengthening bilateral trade relations.
\end{abstract}

Keywords: bilateral trade relation, comparative advantage, export competitiveness. 
The diplomatic relations between Indonesia and Paraguay started since 29th November 1982. But however, in 1958 the first Indonesian President, Soekarno paid an official visit to Paraguay during his visit to the Latin American region. For Indonesia, the bilateral diplomatic relation is handled via the Indonesian Embassy based in Buenos Aires which concurrently accredited for Uruguay and Paraguay. Meanwhile for Paraguay, on January 2011 Paraguay opened the embassy in Jakarta. Further, since 1990 Indonesia has a honorary consulate, Mr. Ricardo Sanchez Abdo in Asuncion and will continue his term until 31 st December 2014 (Keputusan Presiden No. 40/M dated 29th March 2010). Both countries have good diplomatic relations since 1982 and the good bilateral relations was marked by the following important recent visits over the last few years:

1. The official visit of the Indonesian Minister of Foreign Affairs, DR. Hassan Wirajuda to Paraguay on 23-25 August 2007.

2. The bilateral meetings between the Director General for American and European Affairs (MoFA $\mathrm{RI}$ ) with the Vice-Minister for Political Affairs and the Vice-Minister for Economic Affairs (MoFA Paraguay) on $3^{\text {rd }}$ July 2009 in Asuncion, Paraguay.

3. Indonesian Foreign Minister had a bilateral meeting with Paraguayan Foreign Minister on $25^{\text {th }}$ August 2011 during the sidelines of the $5^{\text {th }}$ FEALAC Ministerial Meetings in Buenos Aires.

4. The visit of the Director General for Multilateral Policy from the Paraguay Ministry of Foreign Affairsfor the $6^{\text {th }}$ FEALAC Ministerial Meetings in Bali last June 2013.

For the bilateral socio-cultural relations, both countries signed Memorandum of Understanding (MoU) between the Department of Foreign Affairs of the Republic of Indonesia and the Ministry of Foreign Affairs of the Republic of Paraguay for Cooperation on Diplomatic Education and Training on $28^{\text {th }}$ November 2007 but however the agreement has not yet been used by both sides. Further, there is only one Paraguayan citizen participated for the Indonesian Darmasiswa Scholarship (2006/2007 Academic Year). For sport cooperation, in 2008 the Provincial Government of Nanggroe Aceh Darussalam in collaboration with the PT. Sanchezgol Management (owned by the Chilean citizen in Indonesia) has sent the U-15 Team with a total of 30 football players accompanied by 4 teachers to participate for 3 years football training program in Olimpico Committee Club in Paraguay. But however due to certain matters, the cooperation terminated on September 2009 and the football training was shifted to the Empoli FC (Italian owned) training center in Paraguay. Mean while, for the bilateral consular cooperation, both Minister of Foreign Affairs have signed the Agreement between the Government of the Republic of Indonesia and the Government of the Republic of Paraguay on Visa Exemption for Diplomatic, Official and Service Passports in Asuncion, 24thAugust 2007. This agreement was ratified with the Peraturan Presiden Republik Indonesia No. 37 Year 2009 on $28^{\text {th }}$ August 2009 and entered into force on $6^{\text {th }}$ October 2009. As of July 2011, there are 34 Indonesian citizens which consist of 12 missionaries, 18 football player students from Aceh accompanied by 2 teachers, and 2 Indonesian citizens married with the Paraguayans.

For the economic cooperations, there is still no bilateral economic agreement umbrella but however both countries are still in the process of negotiation for the agreement on economic and technical cooperation. For the bilateral trade relations, in 2012 trade volume was relatively low and only reached US $\$ 37.7$ million and ranked $10^{\text {th }}$ out of 25 countries in South America and Caribbean regions. Indonesian export market share to Paraguay only accounted 0.01 percent of the total Indonesian export, whereas the South America and Caribbean regions represented only 1.38 percent. But however, with exception in 2012, the bilateral trade relations have been steadily increasing over the last few years. 
In 2012 Indonesian main export commodities to Paraguay among others are Cigars, cheroots, cigarillos and cigarettes, of tobacco or of tobacco substitutes (HS 2402), Polyacetals, other polyethers and epoxide resins, in primary forms; polycarbonates, alkyd resins, polyallyl esters and other polyesters, in primary forms (HS 3907),New pneumatic tyres, of rubber (HS 4011), Electric accumulators, including separators there for, whether or not rectangular (including square) (HS8507), Centrifuges, including centrifugal dryers; filtering or purifying machinery and apparatus, for liquids or gases (HS 8421).While Indonesian main imports from Paraguay are Oil-cake and other solid residues, whether or not ground or in the form of pellets, resulting from the extraction of soya bean oil (HS2304),Cotton, not carded or combed (HS5201), and Maize (corn) (HS 1005).

Since the opening of the diplomatic bilateral relations in 1982, Indonesia-Paraguay bilateral trade relations showed certain fluctuations and low trade intensity. It is only over the last few years that the bilateral trade relations have significantly increased. In 1989, the total value of bilateral trade only amounted US $\$ 0.28$ million and now in 2012 reached US\$37.71 million. During the period 19962003, Indonesia-Paraguay bilateral trade relations were one of the lowest levels, reached the lowest in 2003 only amounted U\$2.21 million. During this period, Paraguay experienced 6 years of prolonged economic downturn associated first with a banking crisis, and this problem was exacerbated due to the 1997/98 Asian Financial and Economic turmoil, Russian, Brazil and Argentine crisis and the 2001 global recession. Mean while for Indonesia, the country was badly hit by the 1997/98 Asian Financial Crisis and undergone a major economic and political reform.

Table 1: Trade Relations Between Indonesia-South America and Caribbean Regions Period 20102012 (In Million USD)

\begin{tabular}{|c|c|c|c|c|c|c|c|c|c|c|c|}
\hline \multirow{2}{*}{ No } & \multirow{2}{*}{ Countries } & \multirow{2}{*}{2010} & \multicolumn{4}{|c|}{2011} & \multicolumn{4}{|c|}{2012} & \multirow{2}{*}{$\begin{array}{c}\Delta(\%) \\
2012 / 2011\end{array}$} \\
\hline & & & Export & Import & $\begin{array}{c}\text { Total } \\
\text {. }\end{array}$ & Balance & Export & Import & $\begin{array}{c}\text { Total } \\
\text {. }\end{array}$ & Balance & \\
\hline 1 & Antigua \& Barbuda & 432.80 & 314.00 & $14,605.50$ & $14,919.50$ & $-14,291.50$ & 283.50 & $5,747.70$ & $6,031.20$ & $-5,464.20$ & -59.58 \\
\hline 2 & Argentina & $1,226,241.60$ & $354,470.40$ & 1,585,965.70 & $1,940,436.10$ & $-1,231,495.30$ & $312,538.80$ & $1,756,278.80$ & $2,068,817.60$ & $-1,443,740.00$ & 6.62 \\
\hline 3 & Bahamas & $18,280.60$ & $1,154.70$ & 810.20 & $1,964.90$ & 344.50 & $1,234.30$ & 105.10 & $1,339.40$ & $1,129.20$ & -31.83 \\
\hline 4 & Barbados & $2,743.10$ & $2,837.50$ & 988.40 & $3,825.90$ & $1,849.10$ & $2,332.90$ & $1,147.90$ & $3,480.80$ & $1,185.00$ & -9.02 \\
\hline 5 & Bolvia & $4,129.90$ & $5,725.40$ & 311.10 & $6,036.50$ & $5,414.30$ & $7,338.60$ & $1,165.50$ & $8,504.10$ & $6,173.10$ & 40.88 \\
\hline 6 & Brazil & $3,245,714.60$ & $1,734,907.90$ & $1,898,064.80$ & $3,632,972.70$ & \begin{tabular}{|c|}
$-163,156.90$ \\
\end{tabular} & $1,486,190.70$ & $1,970,951.00$ & $3,457,141.70$ & $-484,760.30$ & -4.84 \\
\hline 7 & Chile & $501,706.50$ & $213,966.90$ & $372,261.50$ & $586,228.40$ & -158,294.60 & $175,346.50$ & $206,640.90$ & $381,987.40$ & $-31,294.40$ & -34.84 \\
\hline 8 & Persemakmuran Dominika & 639.20 & 887.00 & 611.00 & $1,498.00$ & 276.00 & 457.40 & 595.10 & $1,052.50$ & \begin{tabular}{|c|}
-137.70 \\
\end{tabular} & -29.74 \\
\hline 9 & Republik Dominika & $21,249.40$ & $24,188.30$ & $9,298.90$ & $33,487.20$ & $14,889.40$ & $23,145.60$ & $3,842.90$ & $26,988.50$ & $19,302.70$ & \begin{tabular}{|c|}
-19.41 \\
\end{tabular} \\
\hline 10 & Ekuador & $70,196.40$ & $90,137.50$ & $6,478.80$ & $96,616.30$ & $83,658.70$ & $80,895.90$ & $6,830.50$ & $87,726.40$ & $74,065.40$ & -9.20 \\
\hline 11 & Grenada & 468.80 & 208.50 & \begin{tabular}{l|l}
47.60 \\
\end{tabular} & 256.10 & 160.90 & 410.60 & 73.40 & 484.00 & 337.20 & 88.99 \\
\hline 12 & Guyana & $1,452.60$ & $1,615.00$ & 301.00 & $1,916.00$ & $1,314.00$ & $2,923.10$ & $1,311.80$ & $4,234.90$ & $1,611.30$ & 121.03 \\
\hline 13 & Haii & $15,978.40$ & $21,703.00$ & $7,801.40$ & $29,504.40$ & $13,901.60$ & $47,613.60$ & $4,800.50$ & $52,414.10$ & $42,813.10$ & 77.65 \\
\hline 14 & Jamaika & $9,463.30$ & $11,939.70$ & $1,463.20$ & $13,402.90$ & 10,476.50 & $11,026.70$ & 931.20 & $11,957.90$ & $10,095.50$ & -10.78 \\
\hline 15 & Kolombia & $149,664.00$ & $139,492.80$ & $31,955.80$ & $171,448.60$ & $107,537.00$ & $170,656.90$ & $19,529.20$ & $190,186.10$ & $151,127.70$ & 10.93 \\
\hline 16 & Kuba & $10,105.10$ & $15,190.60$ & $1,689.40$ & $16,880.00$ & $13,501.20$ & $\begin{array}{l}12,647.70 \\
\end{array}$ & $1,253.10$ & $13,900.80$ & $11,394.60$ & -17.65 \\
\hline 17 & Paraguay & $32,385.40$ & 19,597.00 & $28,607.50$ & $48,204.50$ & $-9,010.50$ & $18,152.30$ & $19,553.80$ & $37,706.10$ & $-1,401.50$ & -21.78 \\
\hline 18 & Peru & $125,637.60$ & $161,982.60$ & $51,388.60$ & $213,371.20$ & $110,594.00$ & $159,888.30$ & $72,679.00$ & $232,567.30$ & $87,209.30$ & 9.00 \\
\hline 19 & StKitts \& Nevis & 358.80 & 249.50 & 0.00 & 249.50 & 249.50 & 384.83 & 2.20 & 387.03 & 382.63 & 55.12 \\
\hline 20 & StLucia & $1,015.70$ & 483.90 & 0.10 & 484.00 & 483.80 & 415.90 & 129.23 & 545.13 & 286.67 & 12.63 \\
\hline 21 & StVincent \& The Grenadines & 881.10 & 448.10 & 780.90 & $1,229.00$ & -332.80 & 318.11 & $1,579.28$ & $1,897.39$ & $-1,261.17$ & 54.38 \\
\hline 22 & Suriname & $4,797.50$ & $4,715.90$ & $3,215.10$ & $7,931.00$ & $1,500.80$ & $7,097.50$ & $1,829.30$ & $8,926.80$ & $5,268.20$ & 12.56 \\
\hline 23 & Trinidad \&Tobago & $36,246.10$ & $8,197.00$ & $33,601.00$ & $41,798.00$ & $-25,404.00$ & $9,698.20$ & $24,174.70$ & $33,872.90$ & $-14,476.50$ & -18.96 \\
\hline 24 & Uruguay & $38,320.00$ & $44,653.60$ & $17,122.60$ & $61,776.20$ & $27,531.00$ & $38,157.20$ & $19,997.60$ & $58,154.80$ & $18,159.60$ & -5.86 \\
\hline 25 & Venezuela & $65,440.30$ & $127,953.10$ & 862.70 & $128,815.80$ & $127,090.40$ & $96,001.10$ & 690.70 & $96,691.80$ & $95,310.40$ & -24.94 \\
\hline & Total & $5,583,548.80$ & $2,987,019.90$ & $4,068,232.80$ & $7,055,252.70$ & $-1,081,212.90$ & $2,665,156.24$ & $4,121,840.41$ & $6,786,996.65$ & $|-1,456,684.17|$ & -3.80 \\
\hline
\end{tabular}

Source: World Integrated Trade Solution (2013) 
Paraguay has undergone a major turnaround since 2003 and the economy has been growing rapidly. Although in 2012, the Paraguay economic growth declined to 1.2 percent but however it is estimated that in 2013 Paraguay economic growth may reach to 13 percent (Romero, 2013). The same case for Indonesia, although there was a prolonged global economic recession but however over the last few years Indonesia managed to post a relatively high economic growth with 6.49 percent (2011) and 6.23 percent (2012). The strong economic growth has in fact strengthen bilateral trade relations over the last few years. During the period 2008-2012, the average total bilateral trade reached 30.16 percent. With the exception in year 2012, the bilateral trade has significantly increased over last few years. The bilateral trade relations in fact started to reinvigorate since 2007 from a total bilateral trade value of US\$6.95 million and in 2011 reached to an unprecedented level of US\$48.21 million but however the following year declined to US\$37.71 million. Further, during the last 5 years (2008-2012), the average Indonesian export increased by 13.13 percent and meanwhile for the average Indonesia import within the same period rose by 81.68 percent.

Table 2: Trade Relations between Indonesia and Paraguay for the Period 1989-2012 (In Million USD)

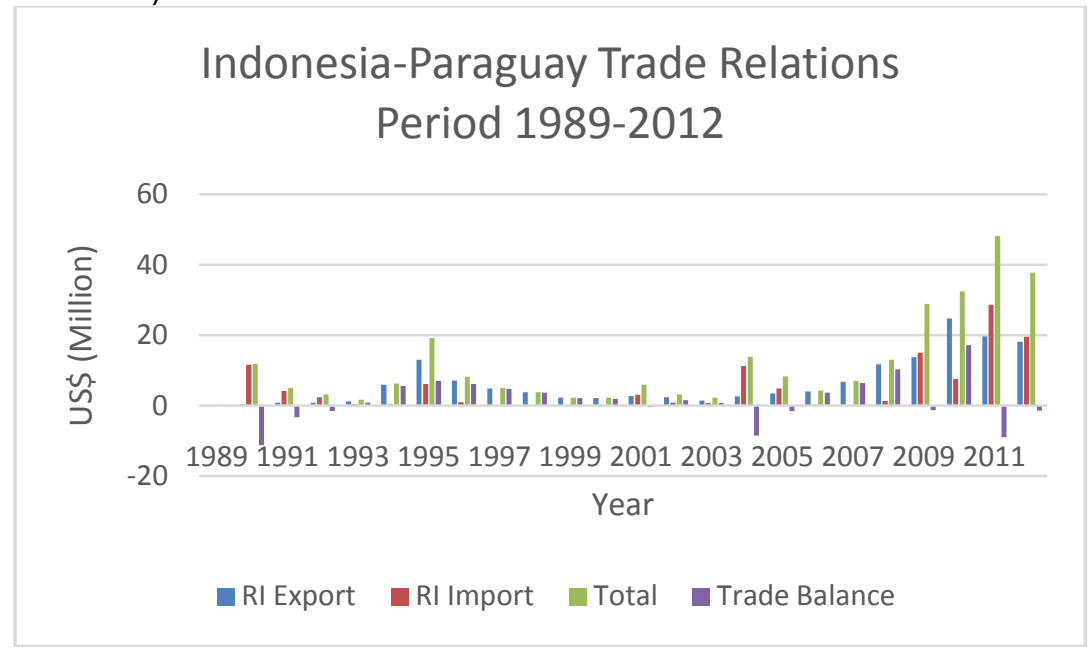

Source: World Integrated Trade Solution (2013)

To enhance bilateral economic relations, Indonesia has conducted the Indonesian Tourism and Culture Promotion (Program Promosi Terpadu Indonesia) in 2007 and 2009, Asuncion. Further on 29th November 2007, Indonesia established Indonesia Business and Cultural Center (IBCC) in Asuncion headed by Indonesian Honorary Consul in Paraguay with the objectives to facilitate business communities from both countries and to promote Indonesian economic, culture and tourism. To enhance trade, every year the Indonesian government has also attempt to bring business communities from Paraguay to participate the Trade Expo Indonesia (TEI) in Jakarta. But however, the potential of the two countries has not been used optimally. There are opportunities to enhance bilateral economic relations. Although Paraguay has only 6 million habitants, a GDP totalling US\$33 billion and a GDP per Capita of US\$5200, but Paraguay highly import consumer goods thus, Paraguay could be a prospective market for Indonesia. This opportunity should be reaped by the Indonesian sides. But however, the same case with the other counterparts within the South American 
and Caribbean regions, there are classical obstacles such as geographical distance, language difficulties and the lack of information which may discouraged both sides to strengthen bilateral trade relations.

Here both sides should need to reinvigorate the private sectors to interact with each other in order to determine the trade potentials in both countries. The momentum of strong economic growth within both countries should be used to further strengthen bilateral economic relations. Both countries have showed some interests to strengthen bilateral economic relations, on one side Indonesian economic diplomacy towards Latin American and Caribbean regions is considered as an alternative market to diversify export markets and have taken more efforts over the last few years due to global economic recession within the traditional markets. Meanwhile for Paraguay, Paraguay started to pay attention to enhance diplomatic relations with the Asia-Pacific countries. On March 2011, although finally did not able to visit Indonesia, but however President Fernando Lugo did visit Vietnam and Taiwan to strengthen economic relations with the Asia-Pacific counter parts. The recent opening of the Paraguayan embassy in Jakarta last January 2011 demonstrated a grand interest from the Paraguay side to increase bilateral relations with Indonesia and its relations within the Asia-Pacific region and this may also show the importance of Indonesia's role within the regional and global affairs (Kemlu, 2011).

Graph 1: Trade Relations between Indonesia and Paraguay for the Period 1989-2012 (In Million USD)

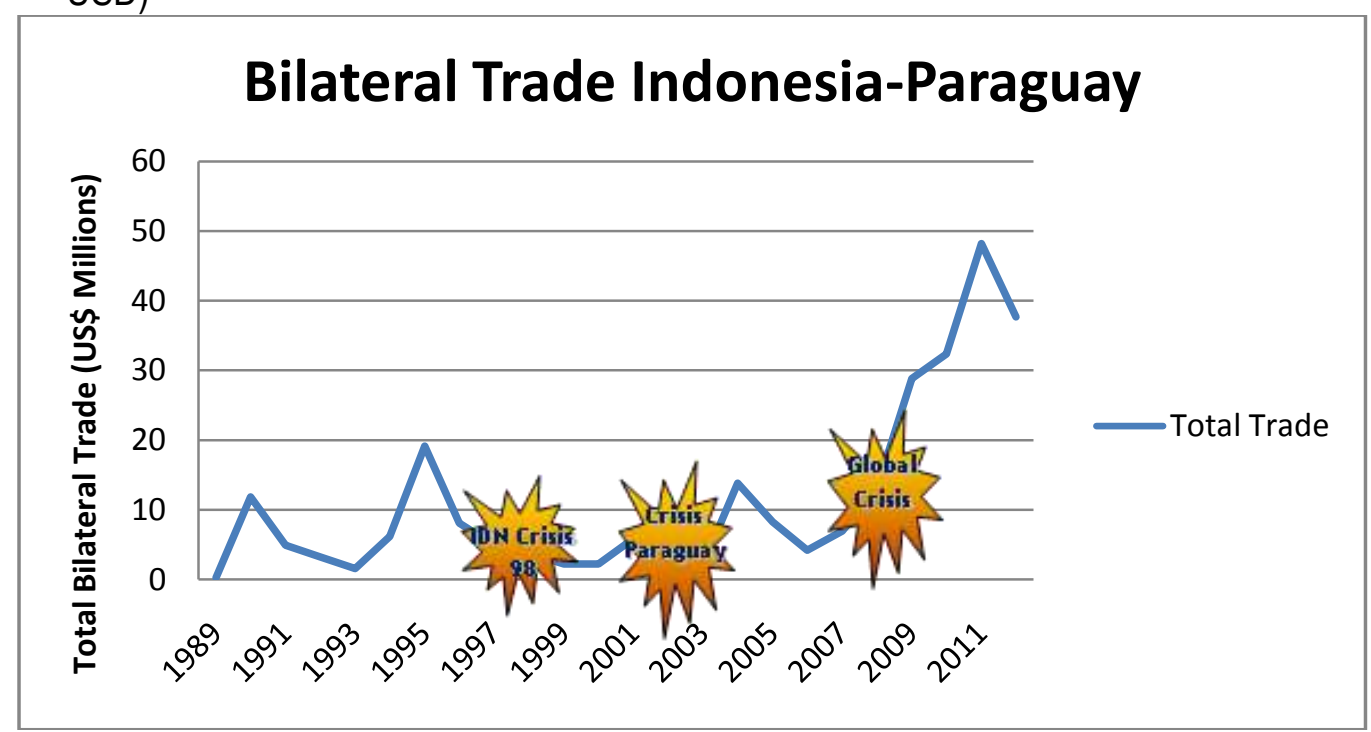

Source: World Integrated Trade Solution (2013)

Few academic papers have been made so far particularly on issues concerning Indonesian economic diplomacy with the Latin American and Caribbean countries andspecifically an academic paper analyzing the Indonesian economic diplomacy towards Paraguay. Thus, this paper attempts to identify and analyze the bilateral trade opportunities based on their respective export competitiveness (or comparative advantage). Therefore, this research paper propose a study with a title of:Exploring Indonesia-Paraguay Trade Potentials: A Revealed Comparative Advantage Approach. This study is expected to contribute in enriching scientific international trade literatures, particularly in the field of 
Indonesian economic diplomacy towards Latin American and Caribbean regions. For the policymakers, the research could be used as a reference for both Indonesian and Paraguayan governments to determine the best economic diplomacy measures in order to strengthen bilateral trade relations.

\section{Method}

A general trade theory stated trade is better than non-trade as trading nations gain from trade through comparative advantage. Further, based on the classical theory of comparative advantage stated that a country with a comparative advantage (comparative disadvantage) in the production of a good should export (import) in order to boost world output (Sodersten, 1994).Some of the prominent trade theories are the Ricardian model in which comparative advantage is based on cross-country technological differences and the Hecksher-Ohlin model, a comparative advantage based on crosscountry endowment differences or a relative factor scarcity. Classical trade theories are based on the principle of comparative advantage concept which derives from relative price determination, such as differences in trade relative prices across countries, based on demand and supply (Ince \& Demir, 2004). In relation with this, Hummels and Klenow (2005) stated the large differences in the export price of similar goods across countries may implies differences in the quantity of goods that countries export.

One of the most widely used to analyze the country's export comparative advantage is by using the Revealed Comparative Advantage (RCA) Index which firstly introduced by Balassa in 1965. RCA Index is one of the "export cum indices" and shows how competitive is a product in countries' export compared to the products share in world trade. A product with high RCA is competitive and can be exported to countries with low RCA. Countries with similar RCA profiles are unlikely to have strong bilateral trade intensities unless intra-industry trade is involved (Chandran, 2010, p. 3). The computation of the RCA index is based on the publication released by Mikic and Gilbert (2009) titled: Trade Statistics in Policymaking: A Handbook of Commonly Used Trade Indices and Indicators and World Integrated Trade Solutions (WITS). The RCA index of country 'i' for product 'j' is often measured by the product's share in the country's exports in relation to its share in world trade:

$$
R C A_{i j}=\frac{X_{i j} / X_{i t}}{X_{w j} / X_{w t}}
$$

Where $x_{i j}$ and $x_{w j}$ are the values of country i's exports of product $j$ and world exports of product $j$ and where $X_{i t}$ and $X_{w t}$ refer to the country's total exports and world total exports. A value of less than unity implies that the country has a revealed comparative disadvantage in the product and vice versa. The present study will use the HS20074 Digits Code (commodity-level) based on the trade data in year 2012 to analyze the Revealed Comparative Advantage Index (RCA Index) of both countries and only the top ten commodities with the highest RCA index in both countries will be discussed in this paper. Thus, this paper attempts to identify and analyze each country's top ten export competitiveness. Based on the results, this paper hopefully could be used by both countries policymakers as a starting point guideline to strengthen bilateral trade relations.

\section{Result and Discussion}

To analyze the export competitiveness of both countries, a Revealed Comparative Advantage (RCA) Index has been used to analyze Indonesia-Paraguay trade potentials. Using the HS 20074 Digits Code and trade data 2012 (commodity-level), the current top ten Indonesian 
exports to Paraguay among others are Cigars, cheroots, cigarillos and cigarettes, of tobacco or of tobacco substitutes (HS 2402), Polyacetals, other polyethers and epoxide resins, in primary forms; polycarbonates, alkyd resins, polyallyl esters and other polyesters, in primary forms (HS 3907),New pneumatic tyres, of rubber (HS 4011), Electric accumulators, including separators therefor, whether or not rectangular (including square) (HS 8507), Centrifuges, including centrifugal dryers; filtering or purifying machinery and apparatus, for liquids or gases (HS 8421).

The top ten Indonesian export commodities to Paraguay represented 87.86 percent of the total Indonesian export to Paraguay in which the top 3 export commodities accounted for 62.91 percent of the total Indonesian export to Paraguay. In general these commodities have relatively strong comparative advantages, but none of the top ten Indonesian export commodities to Paraguay are within the top ten Indonesian strongest export competitiveness (see Table 4).Within the top ten Indonesian commodities exported to Paraguay, there are eight Indonesian export commodities with the RCA index greater than one indicating that Indonesia holds a comparative advantage in these commodities in the world market. As mentioned based on the classical international trade theory that a country with a comparative advantage should export the commodities and vice versa, as this ultimately will benefit the world through higher output meaning a higher welfare.

Table 3: Top-Ten Indonesian Export to Paraguay for the Year 2012.

\begin{tabular}{|c|c|c|c|c|}
\hline $\begin{array}{l}\text { HS } 2007 \\
4 \text { Digits } \\
\end{array}$ & \multirow[t]{2}{*}{ Product Name } & $\begin{array}{l}\text { IDN-PAR } \\
\text { Trade Value }\end{array}$ & \multirow{2}{*}{$\begin{array}{c}\text { RCA } \\
\text { Index (IDN) }\end{array}$} & \multirow{2}{*}{$\begin{array}{c}\text { RCA } \\
\text { Index (PAR) }\end{array}$} \\
\hline Product Code & & in Millions USD & & \\
\hline 2402 & $\begin{array}{l}\text { Cigars, cheroots, cigarillos and cigarettes, of } \\
\text { tobacco or of tobacco substitutes }\end{array}$ & 7,12 & 2,37 & 6,96 \\
\hline 3907 & $\begin{array}{l}\text { Polyacetals, other polyethers and epoxide resins, } \\
\text { in primary forms; polycarbonates, alkyd resins, } \\
\text { polyallyl esters and other polyesters, in primary } \\
\text { forms }\end{array}$ & 2,29 & 0,66 & 0,42 \\
\hline 4011 & New pneumatic tyres, of rubber & 2,00 & 1,66 & 0,38 \\
\hline 8507 & $\begin{array}{l}\text { Electric accumulators, including separators } \\
\text { therefor, whether or not rectangular (including } \\
\text { square) }\end{array}$ & 0,87 & 1,05 & 0,002 \\
\hline 8421 & $\begin{array}{l}\text { Centrifuges, including centrifugal dryers; filtering } \\
\text { or purifying machinery and apparatus, for liquids } \\
\text { or gases }\end{array}$ & 0,83 & 0,25 & 0,006 \\
\hline 5509 & $\begin{array}{l}\text { Yarn (other than sewing thread) of synthetic } \\
\text { staple fibres, not put up for retail sale }\end{array}$ & 0,68 & 12,94 & 1,49 \\
\hline 6403 & $\begin{array}{l}\text { Footwear with outer soles of rubber, plastics, } \\
\text { leather or composition leather and uppers of } \\
\text { leather }\end{array}$ & 0,61 & 4,68 & 0,04 \\
\hline 4802 & $\begin{array}{l}\text { Uncoated paper and paperboard, of a kind used } \\
\text { for writing, printing or other graphic purposes, and } \\
\text { non perforated punch-cards and punch tape } \\
\text { paper, in rolls or rectangular (including square) } \\
\text { sheets, of any size, other than paper of heading } \\
48,01 \text { or } 48,03\end{array}$ & 0,59 & 7,52 & 0,02 \\
\hline 6404 & $\begin{array}{l}\text { Footwear with outer soles of rubber, plastics, } \\
\text { leather or composition leather and uppers of } \\
\text { textile materials. }\end{array}$ & 0,52 & 3,65 & 0,01 \\
\hline 6402 & $\begin{array}{l}\text { Other footwear with outer soles and uppers of } \\
\text { rubber or plastics. }\end{array}$ & 0,42 & 1,68 & 0,64 \\
\hline
\end{tabular}

Source: World Integrated Trade Solution (2013) 
Here it is found that the current Indonesian exports to Paraguay still do not strongly reflected its potential as none of the top ten Indonesian commodities with the strongest comparative advantage do not able to penetrate the Paraguayan market. Paraguay is a market-oriented economy and highly imports consumer goods to fulfill the domestic demand. This should be an opportunity for Indonesia to further explore and expand the export commodities in Paraguay. Here, for Indonesia there is plenty room to boost Indonesian exports to Paraguay based on its export competitiveness, at least starting from the top-ten Indonesian export competitiveness commodities. On the other side, Paraguay should remove any trade barriers at least starting from the top-ten Indonesian export competitiveness commodities as Paraguayan consumers would reap benefits through lower prices and more diverse products to choose. Further, last but not least for Indonesia it is suggested that Indonesian policymakers should attempt to export the so called produk unggulan Indonesia or known as the Indonesian potential products as recommended by the Indonesian Ministry of Trade. These suggested products among others are: leather and leather products, medical instruments and appliances, medicinal herb, processed food, essential oil, fish and fish products, handicraft, jewellery, spices, and stationery non paper (Kemendag, 2013).

Table 4: Top-Ten Indonesian Strongest Export Competitiveness for the Year 2012 (CommodityBased).

\begin{tabular}{|c|c|c|c|}
\hline $\begin{array}{l}\text { HS } 2007 \\
4 \text { Digits }\end{array}$ & \multirow[t]{2}{*}{ Product Name } & $\begin{array}{c}\text { IDN-PAR } \\
\text { Trade Value }\end{array}$ & \multirow[t]{2}{*}{ RCA Index } \\
\hline Product Code & & in Millions USD & \\
\hline 2702 & Lignite, whether or not agglomerated, excluding jet. & 0 & 61,50 \\
\hline 1513 & $\begin{array}{l}\text { Coconut (copra), palm kernel or babassu oil and fractions thereof, } \\
\text { whether or not refined, but not chemically modified. }\end{array}$ & 0 & 46,63 \\
\hline 1511 & $\begin{array}{l}\text { Palm oil and its fractions, whether or not refined, but not } \\
\text { chemically modified. }\end{array}$ & 0 & 39,06 \\
\hline 1203 & Copra. & 0 & 37,13 \\
\hline 2604 & Nickel ores and concentrates. & 0 & 36,18 \\
\hline 2606 & Aluminium ores and concentrates. & 0 & 31,65 \\
\hline 0410 & $\begin{array}{l}\text { Edible products of animal origin, not elsewhere specified or } \\
\text { included. }\end{array}$ & 0 & 31,27 \\
\hline 8001 & Unwrought tin. & 0 & 31,26 \\
\hline 4001 & $\begin{array}{l}\text { Natural rubber, balata, gutta-percha, guayule, chicle and similar } \\
\text { natural gums, in primary forms or in plates, sheets or strip. }\end{array}$ & 0 & 29,02 \\
\hline 0908 & Nutmeg, mace and cardamoms. & 0 & 19,70 \\
\hline
\end{tabular}

Source: World Integrated Trade Solution (2013)

Mean while for the Indonesian top ten imports from Paraguay in 2012 based on the HS 2007 4 Digits Product Code, it is found only eight types of commodities imported from Paraguay with a total of US\$19.55 million and among others are Oil-cake and other solid residues, whether or not ground or in the form of pellets, resulting from the extraction of soyabean oil (HS 2304), Cotton, not carded or combed (HS 5201), and Maize (corn) (HS 1005). These 3 commodties amounted US\$18.87 million and represents 96.5 percent of the total Indonesian imports from Paraguay in 2012. The current commodities imported from Paraguay are not diversified, very concentrated and limited. Six out of eight Indonesian imported commodities from Paraguay have comparative advantages and two of them are within the top ten Paraguayan strongest export competitiveness namely Tanned or crust 
hides and skins of bovine (including buffalo) or equine animals, without hair on, whether or not split, but not further prepared (HS4104), and Maize (Corn) (HS1005) amounted US\$3.97 million or 20 percent of the total Indonesian imports from Paraguay in 2012.

Table 5: Top-Ten Indonesian Imports from Paraguay for the Year 2012.

\begin{tabular}{|c|c|c|c|c|}
\hline $\begin{array}{l}\text { HS } 2007 \\
4 \text { Digits }\end{array}$ & \multirow[t]{2}{*}{ Product Name } & $\begin{array}{c}\text { IDN-PAR } \\
\text { Trade Value }\end{array}$ & \multirow{2}{*}{$\begin{array}{c}\text { RCA } \\
\text { Index (IDN) }\end{array}$} & \multirow{2}{*}{$\begin{array}{c}\text { RCA } \\
\text { Index (PAR) }\end{array}$} \\
\hline Product Code & & in Millions USD & & \\
\hline 2304 & $\begin{array}{l}\text { Oil-cake and other solid residues, whether or not } \\
\text { ground or in the form of pellets, resulting from the } \\
\text { extraction of soyabean oil }\end{array}$ & 8,30 & 0,0002 & 14,56 \\
\hline 5201 & Cotton, not carded or combed & 8,07 & 0,006 & 5,33 \\
\hline 1005 & Maize (corn) & 2,50 & 0,04 & 33,03 \\
\hline 4104 & $\begin{array}{l}\text { Tanned or crust hides and skins of bovine } \\
\text { (including buffalo) or equine animals, without hair } \\
\text { on, whether or not split, but not further prepared. }\end{array}$ & 0,47 & 0,39 & 47,10 \\
\hline 3301 & $\begin{array}{l}\text { Essential oils (terpeneless or not), including } \\
\text { concretes and absolutes; resinoids; extracted } \\
\text { oleoresins; concentrates of essential oils in fats, } \\
\text { in fixed oils, in waxes or the like, obtained by } \\
\text { enfleurage or maceration; terpenic by-products of } \\
\text { the deterp }\end{array}$ & 0,13 & 3,14 & 11,35 \\
\hline 2401 & Unmanufactured tobacco; tobacco refuse. & 0,06 & 1,32 & 2,29 \\
\hline 4504 & $\begin{array}{l}\text { Agglomerated cork (with or without a binding } \\
\text { substance) and articles of agglomerated cork. }\end{array}$ & 0,02 & 0,02 & $\mathrm{n} / \mathrm{a}$ \\
\hline 2915 & $\begin{array}{l}\text { Saturated acyclic monocarboxylic acids and their } \\
\text { anhydrides, halides, peroxides and peroxyacids; } \\
\text { their halogenated, sulphonated, nitrated or } \\
\text { nitrosated derivatives. }\end{array}$ & 0,0002 & 1,47 & 0,0019 \\
\hline n/a & $n / a$ & $\mathrm{n} / \mathrm{a}$ & $\mathrm{n} / \mathrm{a}$ & $\mathrm{n} / \mathrm{a}$ \\
\hline $\mathrm{n} / \mathrm{a}$ & $n / a$ & $\mathrm{n} / \mathrm{a}$ & $\mathrm{n} / \mathrm{a}$ & $\mathrm{n} / \mathrm{a}$ \\
\hline
\end{tabular}

Source: World Integrated Trade Solution (2013)

Current Paraguay's export to Indonesia in general is based on its comparative advantage but however, the same case as with Indonesia, it does not yet reflect its strongest potential commodities, thus, there is still plenty room to further enhance Paraguay exports to Indonesia based on its strongest comparative advantage. In Paraguay, agriculture dominates the economy and exports limited types of agricultural commodities especially soybeans and cotton. Thus, a more diverse range of commodities should be introduced and exported to Indonesia, at least starting from the top ten Paraguay's strongest export competitiveness. For the electric energy (HS2716), Paraguay has one of the biggest hydroelectric power plant in the world. Paraguay has two dams: Itaipu Dam, the world's second largest power-generating capacity, co-owns with Brazil and was established in 1984; and Yacyreta Dam, co-owns with Argentina and was established in 1994. Paraguay is the second largest exporter of electrical power (only behind France) but however only exported to Argentina and Brazil. In 2012, Paraguay exported electrical power to Argentina amounted US\$458 millions and to Brazil almost amounted US\$1.78 billion. For this product, it is seems impossible to export electrical power to Indonesia but however what could both countries do is to engage in a joint project to establish a hydropower plant in Indonesia or for the Paraguay side to provide technical capacity building program on establishing a hydropower plant in Indonesia on a reciprocal basis. The possibility to establish 
such joint project could be one of the important South-South cooperations at a bilateral level and could be a good sample to encourage other countries from the Southeast Asian region and the South American and Caribbean regions to creativity find ways to deepen economic relations between these two regions.

Table 6: Top-Ten Paraguayan Strongest Export Competitiveness for the Year 2012

\begin{tabular}{|c|c|c|c|}
\hline $\begin{array}{l}\text { HS } 2007 \\
4 \text { Digits }\end{array}$ & \multirow[t]{2}{*}{ Product Name } & $\begin{array}{c}\text { IDN-PAR } \\
\text { Trade Value } \\
\end{array}$ & \multirow[t]{2}{*}{ RCA Index } \\
\hline Product Code & & in Millions USD & \\
\hline 2716 & Electrical energy. (optional heading) & 0 & 130,14 \\
\hline 4402 & $\begin{array}{l}\text { Wood charcoal (including shell or nut charcoal), whether or } \\
\text { not agglomerated. }\end{array}$ & 0 & 124,66 \\
\hline 0202 & Meat of bovine animals, frozen. & 0 & 77,68 \\
\hline 1201 & Soya beans, whether or not broken. & 0 & 62,31 \\
\hline 0814 & $\begin{array}{l}\text { Peel of citrus fruit or melons (including watermelons), fresh, } \\
\text { frozen, dried or provisionally preserved in brine, in sulphur } \\
\text { water or in other preservative solutions. }\end{array}$ & 0 & 58,26 \\
\hline 1207 & Other oil seeds and oleaginous fruits, whether or not broken. & 0 & 50,07 \\
\hline 4104 & $\begin{array}{l}\text { Tanned or crust hides and skins of bovine (including buffalo) } \\
\text { or equine animals, without hair on, whether or not split, but } \\
\text { not further prepared. }\end{array}$ & 0,47 & 47,10 \\
\hline 1005 & Maize (corn) & 2,50 & 33,03 \\
\hline 1507 & $\begin{array}{l}\text { Soya-bean oil and its fractions, whether or not refined, but } \\
\text { not chemically modified. }\end{array}$ & 0 & 25,73 \\
\hline 0903 & MatT. & 0 & 25,38 \\
\hline
\end{tabular}

Source: World Integrated Trade Solution (2013)

\section{Conclusion}

The Indonesia-Paraguay bilateral trade relations since the opening of the diplomatic relations are of low trade intensity and with some major fluctuations. It is only over the last few years that the bilateral trade relations have significantly increased. The present study reveals that the current bilateral trade does not reflect its potential, thus, there are huge opportunities for both countries to find ways to further strengthen bilateral trade relations. Using the RCA Index analysis, the study found that in general Indonesian export commodities to Paraguay in 2012 have relatively strong comparative advantages but none of the top ten Indonesian export commodities to Paraguay are within the top ten Indonesian strongest export competitiveness. Further, it is also important to note that Indonesian top 3 export commodities to Paraguay accounted for 62.91 percent of the total Indonesian export to Paraguay. This implies that only limited Indonesian commodities able to penetrate the Paraguay market.

Mean while on the other hand, within the same year it is found that only 8 types of commodities that were exported by Paraguay to Indonesia in which the top 3 Paraguay's export commodities namely; Oil-cake and other solid residues, whether or not ground or in the form of pellets, resulting from the extraction of soyabean oil (HS 2304), Cotton, not carded or combed (HS 5201), and Maize (corn) (HS 1005) accounted for 96.5 percent of the total Paraguay exports to Indonesia. Although in general the current Paraguay's export is based on its comparative advantage, but however, the same case as with Indonesia, it does not yet reflect its strongest potential commodities as only two out of the top eight are within the Paraguay strongest export 
competitiveness. The study showed the current commodities imported from Paraguay are not diversified, very concentrated and limited.

The paper suggests both countries should attempt and allow the top ten strongest export competitiveness to enter both markets. For the Indonesian policy makers, the paper suggests Indonesia to export the potential products (produk unggulan Indonesia) as listed by the Indonesian Ministry of Trade. Further, as Paraguay is the second biggest exporter of electric energy in the world, it is also suggested both countries should engage in a joint project to build a hydro power plant in Indonesia as this could be one of the important South-South cooperations at a bilateral level and could be a good sample to encourage other countries from the Southeast Asian region and the South American and Caribbean regions to creativity find ways to deepen economic relations between these two regions. The increasing volume of bilateral trade relations momentum over the last few years could be a positive sign to further strengthen not only bilateral trade relations but also other aspects of bilateral economic relations. The recent opening of the Paraguay embassy in Jakarta last January 2011 would definitely facilitate bilateral relations, thus, this momentum should be used by both sides to undertake more efforts to further enhance bilateral trade relations.

\section{REFERENCES}

Balassa, B. (1965). Trade Liberalization and Revealed Comparative Advantage, The Manchester School, 33, pp. 99-123.

Chandran, S. (2010). Trade Complementarity and Similarity between India and ASEAN Countries in the Context of the RTA, MPRA Paper No. 29279, p. 3-4, 7 August. Last Retrieved 4 July 2013: http://mpra.ub.uni-muenchen.de/29279/.

Hummels, D., \& P. Klenow. (2005). The Variety and Quality of a Nation's Exports, American Economic Review, 95,pp. 704-723.

Ince, M., \& Demir, M. H. (2004). Comparative Advantage and Competitiveness: Case of Turkey and Germany, Review of Social, Economic and Business Studies, vol. 5/6, Fall 2004-2005, pp. 149-171 Famagusta.

Kemendag. (2013). Export Destination Country for 10 Potential Commodities, Kemendag Online. Available from: http://www.kemendag.go.id/en/economic-profile/10-main-and-potentialcommodities/10-potential-commodities.

Kemlu. (2011). Buku Diplomasi Indonesia 2011, Kemlu Online, p.135. Available from: http://www.kemlu.go.id/Documents/PPTM\%202012/DIPLOMASI\%202011.pdf

Mikic, M., \& Gilbert, J. (2009). Trade Statistics in Policymaking: A Handbook of Commonly Used Trade Indices and Indicators-Revised Edition, United Nations ESCAP, Bangkok. Available from: http://www.unescap.org/tid/publication/tipub2559.pdf

Romero, S. (2013). Boom Times in Paraguay Leave Many Behind, The New York Times, 29 April. Available from: http://www.nytimes.com/2013/04/25/world/americas/boom-times-in-paraguayleave-many-behind.html?pagewanted=all\& $r=0$

Sodersten, B., \& Reed, G. (1994). International Economics, Macmillan Press, London.

World Integrated Trade Solutions. (2013). Trade Indicators. Available from:

http://wits.worldbank.org/WITS/WITS/WITSHELP/Content/Utilities/e1.trade_indicators.htm 